\title{
Is Unofficial Economy a Source of Corruption?
}

Faulend, Michael; Šošić, Vedran

Source / Izvornik: Occasional Paper Series, 1999, 3, 1 - 22

Journal article, Published version

Rad u časopisu, Objavljena verzija rada (izdavačev PDF)

https://doi.org/10.3326/ops.9

Permanent link / Trajna poveznica: https://urn.nsk.hr/urn:nbn:hr:242:312644

Rights / Prava: Attribution-NonCommercial-NoDerivatives 4.0 International/ImenovanjeNekomercijalno-Bez prerada 4.0 međunarodna

Download date / Datum preuzimanja: 2023-04-26

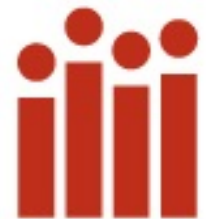

Repository / Repozitorij:

Institute of Public Finance Repository

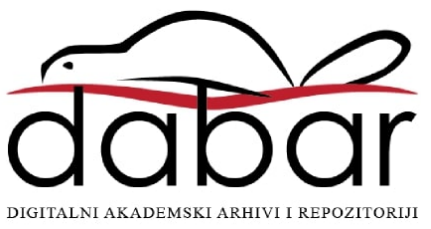




\title{
IS UNOFFICIAL ECONOMY A SOURCE OF CORRUPTION?
}

\author{
Vedran Šošić \& Michael Faulend
}

Occasional Paper No. 9

November 1999

\author{
Institute of Public Finance \\ Katančićeva 5, 10000 Zagreb \\ CROATIA \\ tel: +38514819363 \\ fax: +38514819365 \\ e-mail: office@ijf.hr \\ (C) Institute of Public Finance 1999
}


IS UNOFFICIAL ECONOMY A SOURCE OF CORRUPTION?

\author{
Vedran Šošić \& Michael Faulend
}

\title{
ABSTRACT
}

This paper discusses the link between unofficial economy and overall economic efficiency. Special emphasis is put on tax evasion and corruption and their interaction with unofficial economy.

First, we address the role of the state in the genesis of unofficial economy and corruption. Second part gives more insight into the multitude and ambiguity of definitions used to describe unofficial economy and the impact of the particular definition chosen on the final conclusions. Since we opt for the 'classical' definition of unofficial economy as unrecorded economic activity, we argue that unofficial economy in transition countries, according to this definition, does not hurt economic efficiency and growth.

It is also important to make a distinction between unofficial economy and tax evasion as well as between unofficial economy and corruption. We give an argument in support of the view that those kind of activities are closer linked with official than unofficial economy, as the former uses them as a mechanism for protection from the competition. Unlike unofficial economy, these irregular activities pose more serious threat to general welfare, economic efficiency and growth. We conclude that both unofficial economy and irregular activities are caused by high degree of politicisation and reducing it gives positive impact in reducing both.

In the final part we address the measures required and a policy design which could help preventing irregular activities. This would not completely eliminate unofficial economy, but would remove activities which impair economic efficiency and growth. 


\section{IS UNOFFICIAL ECONOMY A SOURCE OF CORRUPTION?}

\section{Introduction}

During the course of the historically unprecedented transition, opinions differed concerning the appropriate pace of the transition process. However, during course of the process it appeared that the role of the state was not being reduced to the extent necessary and that private entrepreneurship seemed to be developing much slower than expected. Empirical research indicated that in the early years of transition, a significant growth of private sector took place that remained unrecorded in administrative statistics. This can partially be explained by the inertia of statistical services, which for ideological as well as practical reasons did not use statistically adequate procedures to follow activities of private entrepreneurs in centrally-planned economies. More importantly, entrepreneurs decided to enter a sector outside the scope of their states legal protection. This paper concentrates on the reasons that have led entrepreneurs to move into unofficial economy and to the economic implications of the expansion of unofficial economy.

Increased profit was certainly a motivation for entrepreneurial decisions to participate in the unofficial rather than official sector. Each sector has its specific costs and benefits. The paper will focus primarily on those factors that affect the cost of acting in unofficial economy as opposed to the official economy. The size of unofficial economy is negatively affected by increased costs of entering it and repressive measures. In transition countries this could lead, as indicated below in text, to reduced overall efficiency and welfare.

Since unofficial activities represent a form of non-compliance with state regulations, (Feige, 1999) they may actually improve efficiency when the regulations violated represent "bad rules". Therefore, the best way to reduce unofficial activities in transition countries is to reduce the level of politicisation that creates costs for entrepreneurs who operate in the official economy and to prevent politicians from affecting entrepreneurs' profitability by way of arbitrary decisions.

\footnotetext{
${ }^{1}$ This Occasional Paper is the English language translation of the article published in "Financijska praksa", Volume 23, Number 4-5, (October, 1999). Authors are from Croatian National Bank. The views expressed in this paper are those of the authors and do not reflect the position of the CNB or its staff. The authors would like to thank Edgar L. Feige for his very helpful comments and suggestions. The authors are responsible for any remaining errors and omissions.
} 
Business expenses in the official economy often include amounts that must be paid for bribery without the adequate provision of public goods, especially law and order.

\section{Unofficial Economy - Different Views of Different Concepts?}

The interest of scientists and a great number of papers produced both in Croatia and abroad on the role of unofficial economy and its effect on the overall economy have not brought about a consensus on the definition of unofficial economy. Different definitions of unofficial economy attempt to highlight its different aspects.

In literature on Western countries the most exploited concept of unofficial economy is unreported economy which accounts for activities evading tax regulations. On the other hand, unrecorded economic activities, or those activities that escape inclusion in the national accounts, served mostly as an 'academic' subject and sometimes were used as a proxy for calculating unreported income. There are also other activities that deserve to be included in the general category of unofficial economy, but fall short of these two concepts. For example, a deal between the state and a favoured entrepreneur which also includes a hefty reward in return for the favoured treatment will be included in the national statistics and not be considered unofficial economy. In contrast, activities such as selling own home-grown vegetables on the market are not outside the law. Nevertheless, according to this definition - these activities represent unrecorded activities.

Authors aiming at a different focus of analysis will try to overcome this shortcoming with another definition of unofficial economy. A possible approach is also that which labels unofficial economy as all activities not included in the "system of ownership rights guaranteed by the state and system of regulations and obligations which give the economic process and economic activities a legally acceptable and politically legitimate form." (Franičević, 1997a). This concept, also known as the informal economy, is the most frequently used in literature concentrating on the developing economies, but shows a great potential for research on transition economies too (Feige 1990.). This definition encompasses all types of activities that are outside the law, but omits rentseeking redistributive coalitions between politicians, bureaucracy, and interest groups 2 . To

${ }^{2}$ For economists who exclude from their micro-analyses the theory of public choice, the fact that one country can introduce import taxes remains a mystery. However, from the point of view of collective action the introduction of import taxes is much clearer if we consider that they benefit only a relatively small 
broaden the definition to include these activities implemented in institutional structures creates two problems: 1) it enters the area of ethical norms which is characterised by large differences of opinion and is too abstract for applied analysis; and 2) only a small section of economy would remain outside unofficial economy. We prefer to limit our analysis to a consideration of unrecorded activities. When the focus is on fiscal issues, consideration of unreported activities becomes germane.

One of the indirect methods used for measuring tax evasion is to use the assessed size of the unreported economy and multiply it by an average tax rate to arrive at the "tax gap". (Tanzi, 1993) This method may be misleading since tax evasion need not necessarily be connected to the activities of the unrecorded economy. Unreported income arises from not reporting or misreporting income, profits, sales or overreporting deduction items. Such tax evasion does not necessarily imply that economic activities will be excluded from the national income accounts if the accounting methods are independent of tax based source information. It is even possible to imagine case of a country with no unrecorded economy, this fact having no effect on the level of tax evasion.

The major motivation for engaging in economic activities that entrepreneurs attempt to conceal from the state reporting apparatus are regulations and taxes, the former often being the predominant cause. On the one hand, regulations create expenses to companies while on the other hand, they do not create revenues which a state could use for financing certain public goods (e.g. ownership rights protection) of benefit to companies participating in the official economy (Johnson, Kaufmann, and Schleifer, 1997).

Studies on the unofficial economy conducted in the countries with developed economies have presented this sector in an unfavourable light, especially because of this sector's negative influence on economic efficiency and growth (Kesner-Škreb, 1997). Apart from its positive shock-absorbing role in cases of social disturbances, the view generally held is that unofficial economy reduces budget revenue and quality of public goods, distorts macroeconomic indicators and because of simple, work-intensive techniques distorts the allocation of production resources. The implicit assumption behind this line of reasoning is that the demand for public goods from taxes collected is best met by the state and that marginal cost of public regulation equals the

group of producers, while their costs are distributed over a large number of consumers. Even if consumers were informed of the costs imposed by import taxes, low import tax cost for an individual consumer would hinder organising opposition (Olson, 1982). 
regulation's marginal public benefit. However, the situation in transition countries is far from this idealised image of a benevolent state. Moreover, this view does not take into account the role of unofficial economy in transition countries before the introduction of economic and political reforms. "In an economy which is characterised by dominant state ownership, vast private sector restrictions, high taxation of legitimate personal incomes, almost universal price control and physical allocation and rationing of goods, numerous forbidden consumer goods, inefficient and slow formal production and distribution, chronic surplus of currency in circulation, all-level government corruption and important role of personal connections, horizontal and vertical social networks, unofficial economy becomes more than what is marginally official." (Franičević, 1997b).

All arguments speak in favour of the fact that the unofficial economy played a role in promoting economic efficacy in countries where state-imposed distortion mechanisms were at work before transition process started. Obviously there is a difference between the role the unofficial economy played in the centrally planned economies and the role it plays in the countries with developed market economies. This change in the importance of unofficial economy should be achieved by enabling entrepreneurs to move into the official economy sector by means of new regulation and system of taxation.

However, the mechanism at work in the transition countries proved to be completely different from what this theoretical model of the unofficial economy in transition would suggest. Figure 1 shows the evolution of unofficial economy in the first half of the ' 90 's. It presents an unweighted arithmetic mean of share indicators of the unofficial economy in 17 transition countries as assessed by the methodology of electric energy consumption by Johnson, Kaufmann and Schleifer. This estimation method is not fully reliable and has its drawbacks. Besides, other methods have to be employed for the unofficial economy evaluation in the starting year. However, in the absence of better quality data obtained by means of a single methodology covering a longer period of time and a greater number of countries we have to rely on this source. As shown in the figure 1, a strong growth of unofficial economy is evident after the beginning of the transition process.

${ }^{3}$ Countries referred to include Bulgaria, the Czech Republic, Hungary, Poland, Romania, Slovakia, Azerbaijan, Belarus, Estonia, Georgia, Kazakhstan, Latvia, Lithuania, Moldova, Russia, Ukraine, and Uzbekistan. 


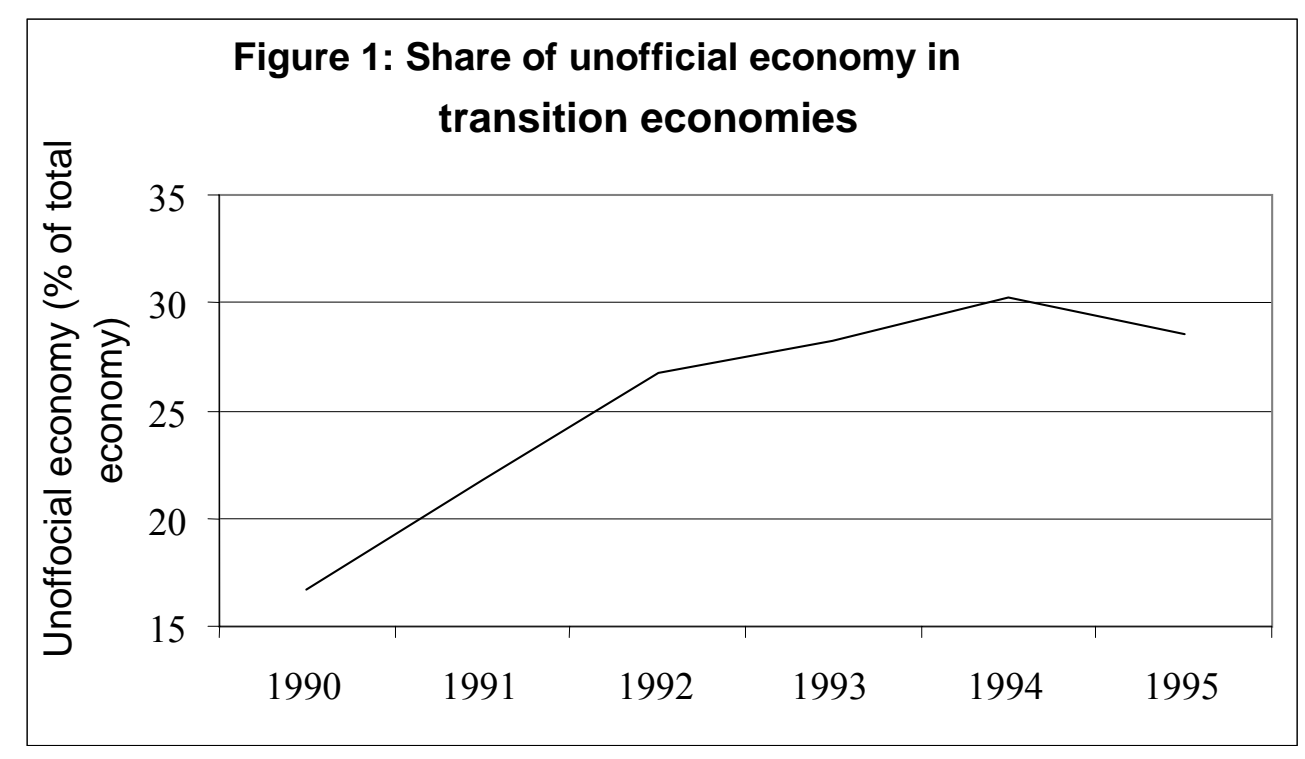

Source: Authors' calculations based on Johnson, Kaufmann and Schleifer (1997), and for Croatia Ott (1997).

This trend should not be interpreted entirely as the result of more intense regulation by the state and higher taxation levels, but rather as a result of reduced political pressure. By political pressure we mean mobilisation of resources by the political elite in order to repress the unofficial economy because of its supposed obtrusive effects for society and presumed effects for the regime, like undermining the social fabric and eroding political legitimacy (Feige, 1999). It is a known fact that political pressure is one of the "more efficient" ways of fighting unofficial economy. The question remains if it is wise to eliminate unofficial economy in this way since the full implications of such methods are not entirely known. In countries with rigid regulations and poor allocation of resources in the public sector (or inefficient provision of public goods) a reduction in unofficial economy would have negative effects on welfare and efficacy.

The rise in transition countries' unofficial economies should not, however, be attributed exclusively to reduced political pressure. The indications are that these states' governments have not done much to keep entrepreneurs away from unofficial economy. Transition countries are still faced with largely politicised economies with high payoffs from rent seeking activities. This results from the absence of the basic institutional rules such as clear property and ownership rights, which represent the basic public good in any given country.

An unofficial economy can benefit consumers in several ways. It can create competitive pressures in markets that are characterised by lack of competition. This is especially important in view of the fact that politicians in transition countries have significant control over entrepreneurs' decisions for entering any specific sector. If unofficial economy participants are concentrated in a smaller number of sectors, their competition will result in lower product prices to consumers' 
benefit (Kesselman, 1995). The unofficial economy may also offer its products at prices lower than those offered by the official economy in the case of non-homogeneity between its products and informed consumers who are willing to pay a lower price for lower quality or lack of product's warranty.

Another way in which unofficial economy can reduce the level of politicised economy is its interaction with tax evasion. Even though tax evasion is not the primary cause of unofficial economy, participants in the unofficial economy generally do not pay taxes because they conceal their business activities. The greater the share of unofficial economy in total economy, the greater the potential tax revenue loss will be. Loss of tax revenue can trigger several reactions - increased taxes, higher borrowing or expenditures' cuts. Borrowing can be perceived as higher tax rates in the future or lower future expenditures. Figure 2 shows the relationship between the share of unofficial economy in the total economy and budget deficit, calculated as averages for the period from 1992-1995. It is evident that, though not strong, there exists a negative relation between the two.

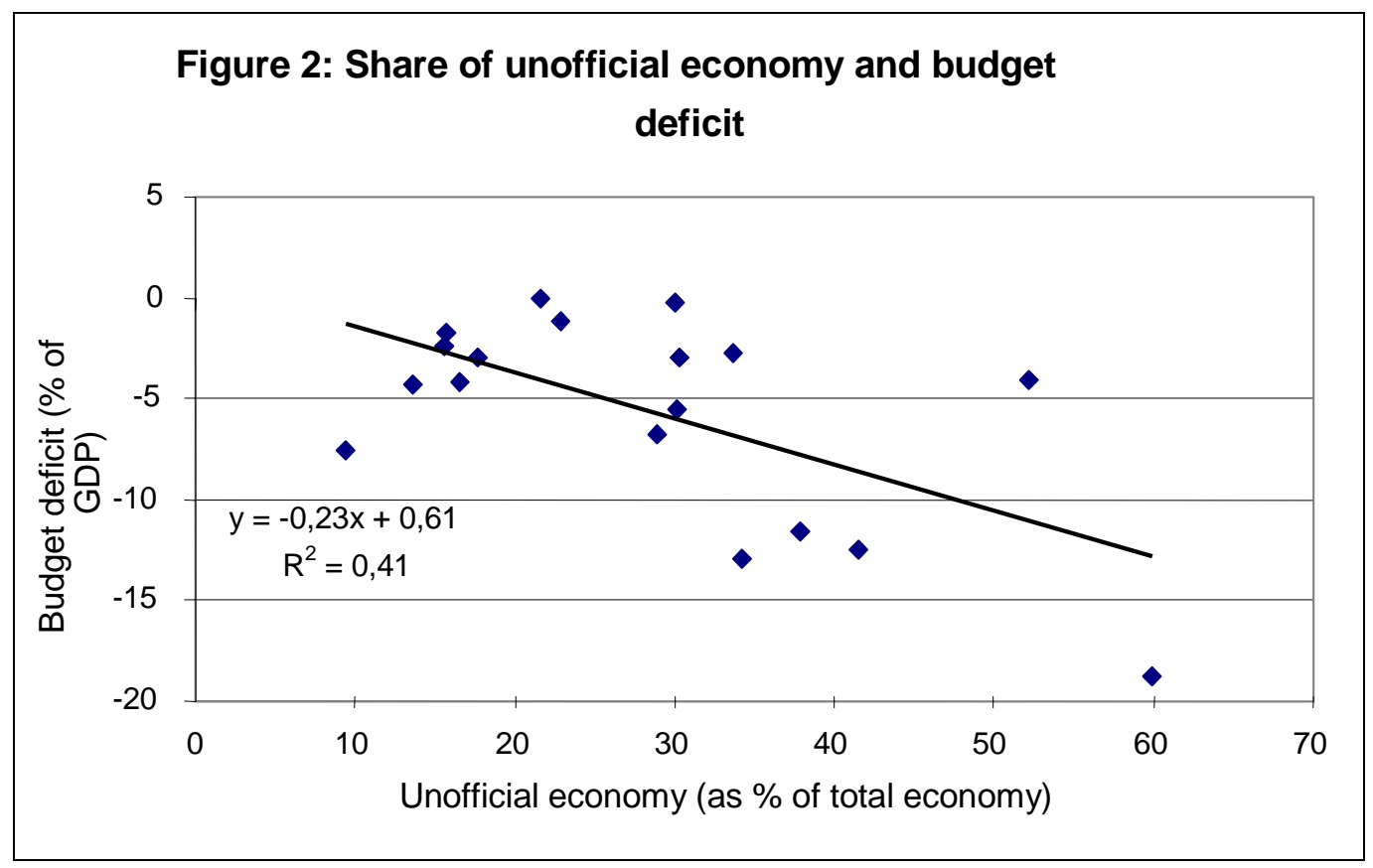

Source: Johnson, Kaufmann and Schleifer (1997) and WIIW (1998), for Croatia Ott (1997) and WIIW (1998).

Figure 3 shows the relationship between the average share of the unofficial economy in the total economy and the average share of budget expenditures in total GDP in the same period, adjusted for the size of the unofficial economy to capture its effect on expenditures. Coefficients 
of determination ${ }^{4}$ point to the fact that this relationship is more significant than the previous one and the equation parameters prove it to be stronger too. Evaluations of linear regressions of these two relationships showed that a one percent increase in the share of unofficial economy in the total economy brought about, on average, an increase in the budget deficit of $0.23 \%$ of the GDP and a decrease in the share of expenditures in the total GDP of $0.53 \%$ of the GDP. It is obvious that in the transition countries an increase in the unofficial economy results in reduced government spending rather than in greater borrowing. The effect of lower government share in GDP on overall efficiency is difficult to discuss without a detailed analysis of government apparatus efficacy and optimal expenditure level. However, as indicated in a previous paper, the level of government spending in the transition countries was found to be too high with regard to these countries' level of development (Faulend and Šošić, 1999). This analysis also suggests that the inclusion of unofficial economy into official economy and a reduction of tax gap ${ }^{5}$ would cause an increase in government expenditures rather than a decrease in the taxation levels. An alternative view argues that the institutional factors that give rise to unofficial economy also affect tax evasion, which is independent of unofficial economy. Institutional changes will decrease both tax evasion and the unofficial economy. Regardless of which explanation may be true, it is clear that transition countries tend to spend as much as possible, rather than to adjust their spending to some outside parameter which would consider the level of optimal spending.

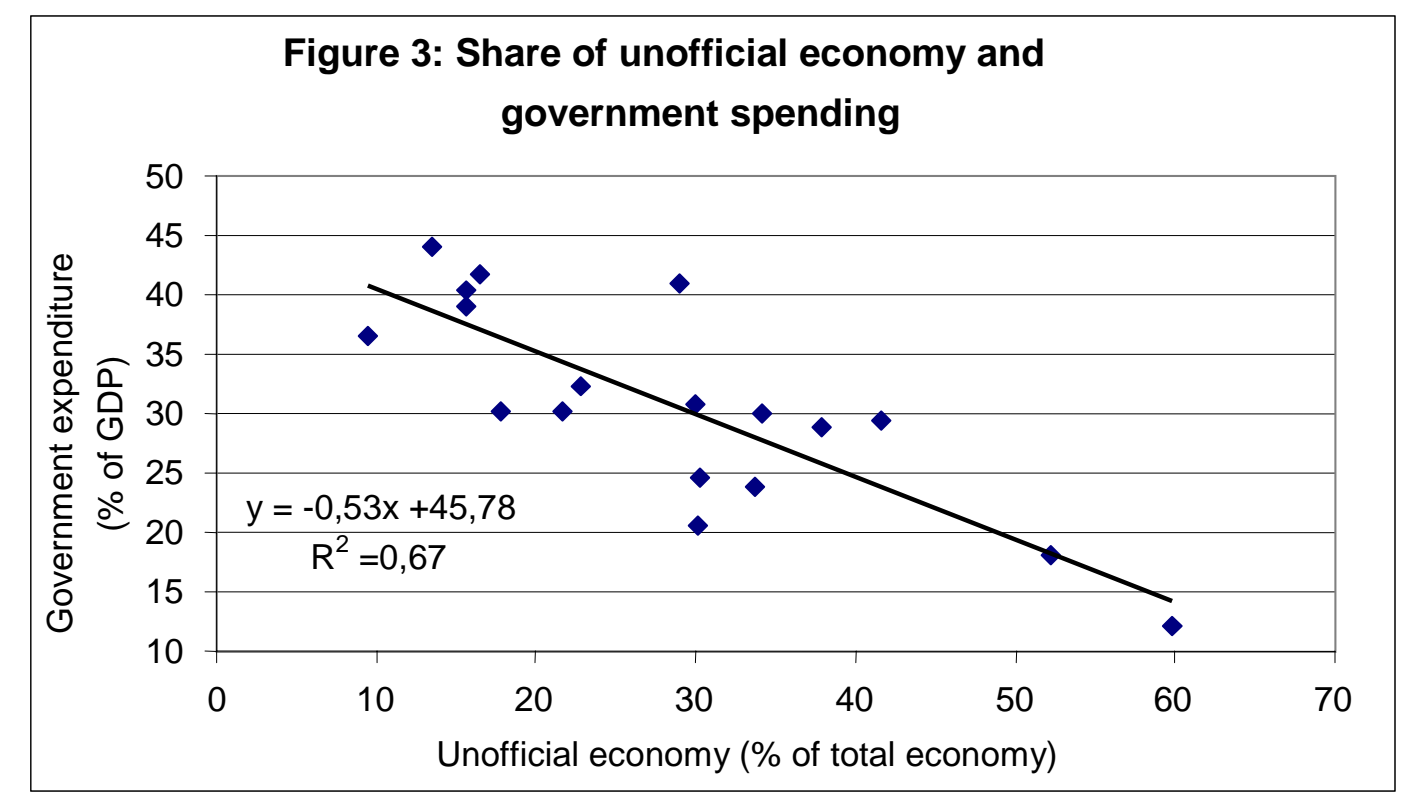

${ }^{4}$ The available data on 18 transition countries do not provide sufficient information to enable unreserved acceptance of these conclusions.

${ }^{5}$ Regardless of the discussed differences between unofficial economy and tax evasion, we suppose that reduced unofficial economy would lead to reduced tax evasion. 
The most frequent arguments in favour of relative efficiency of official economy compared to unofficial economy are its access to public goods that include the already mentioned protection of ownership rights and access to judicial system. Entrepreneurs operating in unofficial economy cannot use these facilities. If these basic preconditions for efficient functioning of the official economy are not met, or if there reigns legal insecurity and judiciary inefficacy, the comparative advantages of official over unofficial economy are lost together with the overall high efficiency of the whole sector of official economy. If they cannot exercise their rights by institutional means, the participants in the official economy may, in an effort to overcome such a shortcoming, turn to the political elite for connections. This may result in numerous side-effects which are discussed in the following chapter.

Privatisation is an issue with a serious possible impact on the relative efficiency of the official economy. Recent findings on comparisons between performances of companies with different backgrounds show "de novo" companies to be the greatest employment and growth generators while companies, which emerged before the transition, were mostly found to be laying off workers and reducing production. (Bojnec and Konings, 1998). While the major part of official economy in transition countries has undergone or still has to undergo privatisation, companies in the unofficial economy sector are not state owned. This fact actually stresses the significance of unofficial economy as an "entrepreneurs' nursery garden" which is especially important for the transition countries which did not use to promote entrepreneurship.

When discussing the dynamic aspect of unofficial and official economy efficiency, it is useful to observe them with regard to the issue of restructuring. The change in ownership structure in itself is just a nominal change of no benefit to the economy. Privatisation should actually serve as an introduction to the restructuring process. The increased allocation efficiency that should accompany stabilisation, privatisation and restructuring processes cannot be separated from legal security and the system's transparency in contrast with politicised economy. Therefore, economic growth, as the final test and final evaluation of all the efforts exerted by transition countries in building their markets, will depend on the success they achieve in limiting the extent of politicisation of their economies.

\section{Corruption and Institutional Factors}


When official and unofficial sectors are discussed in general, the official sector has a positive connotation and the unofficial negative one, since this is the sector where bribery and corruption are predominant. The authors of this paper do not intend to contest the established belief, but to encourage further discussion on the interaction between official and unofficial sectors, the state and corruption. One intriguing assertion suggests that corruption predominantly takes place in the official sector and that corruption in the official economy accounts for the rise and development of the unofficial sector.

Corruption is a phenomenon not related only to the transition and other less developed countries. It is a phenomenon dependent on human behaviour and as such appears in all the countries irrespective of the level of their economic and political development. Nevertheless, the incentives for corruption occur more frequently less developed countries ${ }^{6}$. The reason for a more frequent corruption present in less developed countries can be in the abundance of elements that stimulate corruption, and that are more pronounced in less developed countries. Both direct and indirect elements stimulate corruption. (Tanzi, 1998). Direct elements include regulations and authorisations, taxation, making decisions on government expenditure, various discretionary decisions, and financing of political parties. Indirect factors are related to direct ones, encompassing: bureaucracy quality, level of public sector wages, penalty system, institutional controls, transparency of rules, laws and processes, and examples by the leadership. Less developed countries are generally more regulated, since governments are unable to stimulate individual industries by financial means because of the lack of funds. In such conditions, regulations sometimes present the only way by which a state can stimulate individual sectors and industries. Small companies in these countries transfer to unofficial economy because of the disloyal competition (regulations and authorisations) and relatively high tax burden in the official sector. A shrinking official sector additionally reduces the tax base, which adds pressure for further increases in taxes. Decision making on government expenditure is mainly discretionary. In that way, particular economic units from the official sector are favoured, which additionally strengthens their monopolistic position. Accordingly, these economic units often support the ruling party. Bureaucracy quality in terms of public servants quality greatly depends on the amount of salary within the public sector and allocation of human resources. Employees often

${ }^{6}$ This is supported by the corruption perception index list for several countries published by Transparency International every year. 
hold inappropriate positions, which has an adverse effect on the efficacy of public service. Additionally, more educated and qualified staff leaves the public sector due to better financial conditions offered by the private sector. Inadequate penalty systems, as well as inadequate institutional controls, enable malpractice of public servants mainly in terms of discretionary decisions. The absence of transparent rules and laws additionally induces public servants to make discretionary decisions and misuse their authority. Finally, the example of state governing indicated by Tanzi, together with the example of all leaders of individual public institutions, significantly contributes to adequate conduct of the staff in lower positions.

Naturally, the question arises why all these elements are more pronounced in transition countries. Although economic reasons can certainly account for many things, transition does not only involve economic transformation, but also implies political transformationt 7 . Conduct of politicians in transition countries has not significantly changed when compared to the previous behaviour of politicians in centrally-planned economies. Politicians frequently use their positions to pursue their own interests. Accordingly, they castigate entrepreneurs from the opposing parties, and support those from the "friendly" parties (Johnson, Kaufman, Shleifer, 1997). They also abuse their power and become rich by offering exemption from various levies in exchange for a bribe.

The above-mentioned forms of behaviour that, apart from bribery, include extortion, blackmail, and nepotism, are classical examples of corruption. Corruption must have sociological roots as well (Faulend, 1998). However, corruption is generally considered to be an inevitable characteristic of particular social, economic, and political transformations in situations of weak institutional frameworks, limited competition, and vague distinctions between public and private activities. Weakness of institutional framework present in the transition countries could be the main reason for more pronounced direct and indirect elements stimulating corruption. Politicisation of economic processes, presenting at the same time the cause and consequence of institutional framework and the source of corruption-related activities, must not be disregarded.

It is not surprising that corruption is most frequently related to the public sector, which accounts for a demand for corruption. The supply side of the market for corruption is made up of individual economic units from the official sector, who offer bribes to public servants in order to

${ }^{7}$ Most of the transition countries have made a greater progress in the area of economy (Transition Report 1998). 
be allowed to transact certain business, authorisations, etc. They directly weaken their competition by undertaking such activities. These interest groups generally arise in pre-election periods when individual economic entities finance political campaigns of certain politicians, with an aim to be returned a business favour when these politicians come to power. The connection established between politicians and businessmen is an obvious example of politicisation that has an adverse effect on market competition. Politicisation of economic processes will increase under conditions of insufficiently developed institutional framework, which will create preconditions for corruption to enter all aspects of economic and political life. The final result could be a systemic, or endemic corruption that forms an integral part of the system. In a country where corruption has developed a systemic character, the interaction between politics and segments of official sector is so strong that it puts an enormous pressure on the remaining segment of the official sector. Under such conditions, it is natural for some entrepreneurs from the official sector who are not favoured to move to the unofficial sector. The above mentioned facts support the initial assertion that corruption in the relation official economy - state accounts for the development of unofficial economy. In these circumstances, the unofficial sector is not a cause, but a consequence of corruption and politicisation of economic processes in general.

Empirical research, conducted with an aim of establishing the connection between corruption and unofficial sector, is rather limited due to insufficient data. The research was thus carried out only for some transition countries. Corruption level indicators were adopted from the international organisation, Transparency International, and data from the previous chapter were used as indicators of unofficial sector size. The data from the above stated sources should be treated with considerable reserve, since these are the data on phenomena that cannot be quantified. Tanzi stated on one occasion: "If corruption could be calculated, it could be eliminated as well". The same analogy can be applied to the unofficial sector. In that respect, it should be kept in mind that data, as well as the analysis results are indicative. Figure 4 shows the relationship between the corruption level and size of unofficial sector for some transition countries. It should be noted that corruption level can range from 0 to 10 , where 0 presents maximally corrupted environment and 10 indicates a complete lack of corruption. Therefore, it could be observed that there is a positive relationship between corruption level and unofficial sector, since greater corruption (lower numerical values) corresponds to a greater share of

\footnotetext{
${ }^{8}$ It should be stressed that these are not selected transition countries, but the countries for which both information (corruption index and unofficial sector size) were available. Countries included in the research were the following: Bulgaria, Czech Republic, Hungary, Poland, Romania, Slovakia, Belarus, Estonia, Latvia and Russia.
} 
unofficial sector. The empirical data support the assertion that a higher level of corruption, which is a consequence of increased politicisation of economic processes, expands the unofficial sector.

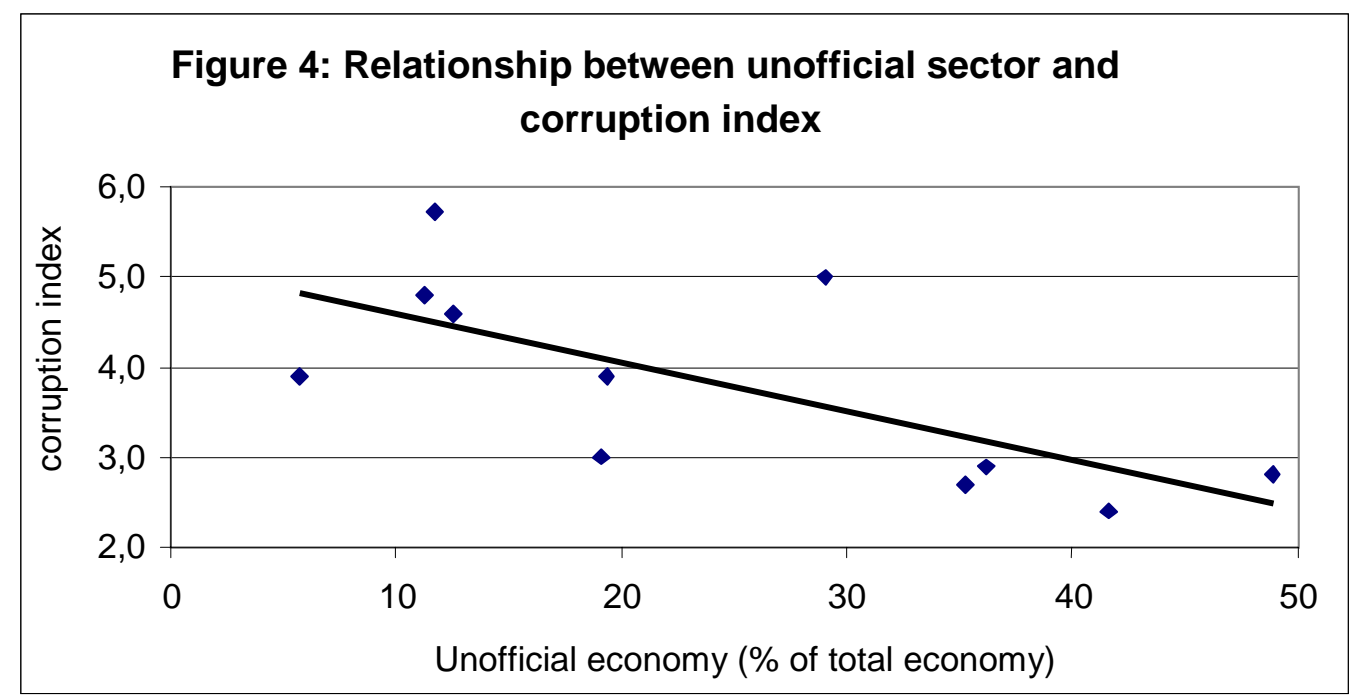

Source: Johnson, Kaufmann and Schleifer (1997), and Transparency International (1998).

Politicisation of economic processes arising from the relationship between political and economic circles definitively presents the main source of corruption in transition countries. Prevention of corruption as well as further development and elimination of the existing corruption are unavoidable tasks assigned to the institutional framework of transition countries. The main aim of the systematic anti-corruptive strategy implementation is a distinction between the area of private and public activities, which presents the basis for severing connections between individual economic and political circles. It is a historic fact that institution-strengthening process is parallel with democratisation of society. A political consensus in parliament is thus a precondition for implementing any anti-corruption strategy. If there were an adequate institutional framework in transition countries that would prevent, by eliminating corruption, the interaction between a segment of the official sector and state, the official sector regulation could be reduced. Reduced regulation would limit the discretionary power of public servants, and enable greater competition. A decreased level of politicisation would have a positive impact on the quality of public goods supplied and permit a decrease in the tax burden. This would in turn influence economic units, previously forced to work in the unofficial sector, to transfer to the official sector. In short, the result would be increased competition, better resource allocation, improved efficiency and welfare. 


\section{Politicisation of the Croatian economy}

The conceptual problems related to the study of sources of unofficial economy come to light when we review specific instances of the issue of involvement of politics in economy. To illustrate some of the aforementioned issues, we shall focus here only on the recent activities of the state in Croatia in four areas: in privatisation, in generating arrears, in its relation with commercial banks and the central bank. Each of these issues is studied separately in this paper. However, as we show, their mutual interaction is also relevant because it has proved to be a fertile ground for political intervention in the Croatian economy.

Privatisation processes in transition economies gave opportunity for the consolidation of transition countries' governments. Privatisation has enabled politicians to reward political loyalty with special access to state property. In Croatia, privatisation was done through sales on a caseby-case basis and privatization decisions were centralized by the state administration. Croatian legislation had important shortcomings, that allowed privatisation outcomes to be affected by political clientism, granting of credits by state banks without corresponding collateral, "privatization" of companies' profits by incumbent managers at the expense of other shareholders, and use of company cash-flow to pay for shares and other criminal activities (Čučković, 1997).

In Croatia, the ownership transformation of 2650 companies ${ }^{2}$ (Privatizacija, 1998). has resulted in 908 legal proceedings in competent courts initiated against the $\mathrm{CP} \stackrel{10}{10}$. Thus, more than one third of all companies which have undergone ownership transformation feel that they were not accorded their due rights (Banka, 1999). Moreover, 9 company ownership transformations were completely and 94 were partially annulled. Annulment of ownership registration is possible only within three years following share registration in the share register. Therefore it seems likely that ownership of privatised companies' shares will consolidate regardless of the manner of their acquisition. A large number of companies were bought on instalment plan, which did not, however, affect their new owners' right to immediate management. A little more than a year ago an intensive trend was observed in connection with some of these companies. Unable to fulfil their obligations towards the CPF they began being returned to state ownership. Their adverse financial positions could be explained by the fact that a significant part of their resources went

${ }^{9}$ Ownership transformation differs from privatisation. There are companies which have undergone transformation and are under majority or minority ownership of Croatian Privatisation Fund or Retirement Fund.

\footnotetext{
${ }^{10}$ Croatian Privatisation Fund
} 
"private". These failuresversely effected the state, tax payers-creditors and the banks which extended loans to these companies.

The role of the state in the genesis of the issue of arrears in Croatia is not completely clear. The fact that someone is a net creditor is a poor excuse not accepted by the state for nonpayment of debts and should not be used by it either. The state's failure to meet its payment obligations can be seen in the 2008 cases registered at the Zagreb Municipal Court between 1990 and $30^{\text {th }}$ October 1998 with the state as debtor (Poslovni svijet, November 25, 1998). This accounts for less than 5 percent of foreclosure cases on that court. The figure would be increased if dismissed suits filed by companies against the state were added. There are also cases when companies do not even invoice state ministries for services rendered or goods supplied unless they get a tip these will be paid. In this way they knowingly break the law by not paying VAT on the uninvoiced amount, regardless of the fact that the state is a debtor who is late with payment. An additional feature that discourages companies from seeking settlement of their claims in court is the fact that the Payments' Institute tends to refuse to execute courts' foreclosure orders (Poslovni svijet, December 25, 1998). Once such practices are established, ministries gain more power to make discretionary decisions as to who gets paid first. Some officials are willing to "help" when adequately compensated for their service (Banka, November 1998).

Given the fact that the state is also a large creditor, a similar atmosphere of preferences can be created with regard to its claims. If certain companies are excused from settling their obligations towards the state, it is hard to expect strict adherence to rules from other companies. The state's contribution to the problem of arrears in Croatia may not be so large with regard to its amount, but it has certainly had a very important "demonstration effect". If the state is late with its payments and does not pay default interest on them, why should anybody else do so? In view of all this, it is not surprising that the State Treasury project 11 , initiated in 1993 is still (mid 1999)

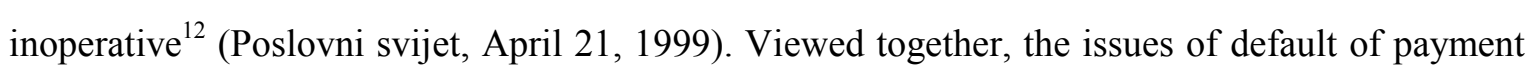
and the slow implementation of the State Treasury project clearly indicate there are interests opposed to any centralised management of state expenditures.

11 The project of building a State Treasury includes the creation of an information system that integrates all state entities (ministries, agencies, extrabudgetary funds, etc.). This would allow overall control of expenditures. Also, possible misuses or irregularities would be minimized.

${ }^{12}$ State Treasury was planned to go into operation at the end of 1996. 
The scope of interaction between the state and commercial banks and the central bank and the degree of politicisation of the banking system cannot be determined with precision. But it is evident that this interaction exists and that it can partly be blamed for the banking system crisis which erupted in Croatia in 1998. In its 1998 Annual Report, the Croatian National Bank pointed out three major causes of banking crisis. "First, poor lending policies of some banks which was not based on market criteria and proper risk assessment resulted in these banks' poor asset quality. Secondly, too high interest rates, and thirdly, inadequate experience in matters relating to bank acquisitions, bankruptcy or liquidation of banks." The first cause which is described as credit policy not based on market criteria actually means connected lending. Some bankers will offer preferential treatment to good friends, relatives, and recommended acquaintances in the form of loans under lower interest rates, uncollateralised loans or some other benefits. Naturally, not every loan extended under non-market conditions implies involvement of politics. However, in the case that a "favourable" loan is granted to a person belonging to the ruling party or that it is granted on the basis of a recommendation coming form a person from the party in power, then we can talk about elements of the politicisation of the banking system. This type of involvement can be found in both state and private banks. Because of a greater extent of reliance, political interest may be more pronounced in state banks. However, this does not have to be the rule. A recent example of political interest in a state bank is the meeting which took place between Mr. Mateša, the Prime Minister and Božo Prka, Managing Director of Privredna banka Zagreb, a large state bank on the occasion of the protest by employees of Nama, the largest national chain store. The protest was provoked after the negotiations between Nama's management board and Privredna banka concerning loan payment extension failed. The failure to reach an agreement meant that the store's outlets would put up for sale and its workers laid off. The protest, involving a hunger strike of nine Nama's employees, in the current socially tense situation, prompted the Prime Minister to arrange a meeting with the Privredna banka Zagreb Managing Director. As a result of the conversation, sales of Nama's stores were immediately halted (Poslovni svijet, May 5, 1999).

That political intervention in private banks is not unknown is shown by the fact that the six banks ${ }^{13}$ faced with difficulties in 1998, out of the total of sixty banks, were all private banks. There were speculations in the media at the time as to the involvement of certain ruling party individuals into scandals relating to bank failures. The ongoing court investigations of the failed

${ }^{13}$ Four of these banks belonged to the group of small banks, two to medium-sized banks. Three banks had undergone procedure for evaluating economic feasibility of rehabilitation. It was decided that rehabilitation was feasible only in the case of Dubrovačka banka, the largest of the six banks. Bankruptcy proceedings were initiated in the remaining five banks. 
banks' leading managers will show how relevant these speculations were. They will also reveal the extent of political involvement and how much it contributed to the banks' failures.

The banking crisis also challenged the independence of the central bank. Prompted by the problems in Dubrovačka banka at the beginning of 1998, the Croatian National Bank put forward a proposal for the foundation of a State Co-ordination Committee for Banking. However, as the media correctly reported "The CNB's report to the Parliament on the Conditions of the Banking Sector which exposed the risky business operations of some banks met with no response as did its proposal to set up new financial bodies. Obviously the central bank has difficulty in winning political support for its views of the situation". The same article also quotes: "Although the draft Banking Law really affords greater and better defined authority to the Croatian National Bank, it does not seem likely that the present legislation prevents the Central Bank from acting to such an extent that several banks in Croatia have already been effectively excluded from the financial system, but are now in limbo and none dares to deal with them without word from above. Evidently, the Croatian National Bank knew what was going on, it kept the Parliament informed and was willing to take proper action. But it seems as though its hands were tied by political directives. We have to face the truth, especially at the moment when initiatives are taken by the country's top executive power for the founding of a co-ordination body" (Poslovni svijet, November 11, 1998). The Central Bank came under pressure from the banking circles as well. The most notable example of this is the pressing demand made by Marko Marčinko, Managing Director of Glumina bank $\frac{14}{4}$ on the CNB to give a positive evaluation for the feasibility of rehabilitation of Glumina banka. Despite the pressure, a bankruptcy proceeding was started in the bank and its Managing Director, Marčinko came under pre-trial investigations. This shows that the Central Bank has won itself some degree of independence, but this independence is fragile and still requires the support offered of the state to resolve the banking crisis.

The involvement of politics in described areas of economic life is characterised by complex interrelation. Certainly, privatisation based on non-market criteria had a negative impact on privatised companies' efficacy and liquidity. Arrears also brought about the exhaustion of companies' funds before they were put up as candidates for rehabilitation. The involvement of politics in banking also did its share in supporting this type of privatisation thereby putting pressure on the banking supervision.

\footnotetext{
${ }^{14}$ One of the six failed banks.
} 
Highly indebted companies as well as some professionals have repeatedly criticised the CNB's policy of maintaining stability of the exchange rate and price level. Conditions characterised by high inflation and arrears are profitable for those who would need to change their business habits in stable conditions. It follows that legal protection of ownership, which we stress to be one of the basic elements of public good and basic motivation for operating within official economy framework, still does not work properly.

Freeing the economy from political ties and creating the rule of law are basic preconditions for growth. The change cannot be made overnight. A political consensus has to be reached on the issue. Draft of general anticorruption strategy, envisaged to follow the political consensus with the basic aim of preventing abuse of power and of discretionary authority of civil servants is given in the final section below.

\section{Conclusions}

The authors of this paper do not support the view that stimulation of unofficial economy in transition countries could be beneficial. On the contrary, every transition country should set as one of its goals the reduction of unofficial economy share in the overall economy. However, unofficial economy in the transition process has had positive impacts that should not be rejected $a$ priori or considered exclusively as social shock-absorbers. Positive impacts of unofficial economy, that mainly include stimulation of efficiency and growth, are important in cases when the system is regulated to such extent that implementation of regulations on the part of a company decreases the overall welfare of society. The lack of expert staff capable of evaluating influences of overall regulations on economy is not necessarily the only reason for such conduct of the state. Other reasons could be a question of political economy, reflecting the extent to which the political elite strives to maintain control over economy for the purpose of realisation of its interests.

Under such conditions, it would be inappropriate to react with repressive measures to the occurrence of unofficial economy, since these measures would impair the initiation of entrepreneurship and would have an adverse effect on the present welfare and growth in the dynamic perspective. Development and implementation of strategy with an aim to reduce the level of politicisation of economic processes would have a more favourable impact on the economic environment. The existing welfare and economic growth would thus not be threatened and preconditions for the mid-term and long-term unofficial economy reduction would be created. Such strategy would imply a systematic anti-corruption strategy based on three pillars. 
The first pillar would be based on administrative and legal reforms. The main idea is to simplify and rationalise the existing rules in order to limit the discretionary power of public servants and thereby reduce the scope of rent seeking activities. This implies establishment or improvement of the existing internal controls which would enable enhanced supervision of public servants with an aim to increase the probability of irregular activities detection.

The second pillar would be based on morality. The aim is to publicly disclose and punish the corrupt public servants and other people from the official sector participating in the corruption process. The main goal of the morality approach is to form a negative public opinion on corruption and detect the weak points of the systems where corruption occurs.

The last pillar would be based on systematic reforms, which imply macroeconomic and structural reforms in general. The aim is to reduce the role of state ${ }^{15}$, i.e. eliminate conditions enabling the development of politicisation and corruption. Systematic reforms encompass three types of complementary policies. First, policies aiming to rationalise the role of state in economy by deregulation, liberalisation, and privatisation. Second, reform policies for the remaining state functions that enhance governing institutions and provide the minimal level of transparency. Finally, there are policies with an aim to create a competitive environment where rules of the game are clearly defined, enabling effective market operations.

A continuous and systematic implementation of the above discussed anti-corruptive strategy, particularly its third part, will enable corruption prevention even in those countries where corruption has developed a systemic character. Decreased level of corruption, which implies the reduced level of politicisation of economic processes, will have a positive impact on overall welfare and economic growtl1 , and will, at the same time, create preconditions for the reduction of the unofficial sector.

${ }^{15}$ It is important to note that one of the main roots of corruption is too extensive state apparatus that is mainly reflected in huge public sector, too many complicated rules, and high tax and tariff rates.

${ }^{16}$ Paolo Mauro performed an analysis on the sample of several countries within a longer time period and established that if a country improved its corruption index by two units, the economic growth rate at the annual level would increase by a half of the percentage point (Mauro, 1996). 


\section{REFERENCES:}

Burgess, R. and Stern, N. (1993), "Taxation and Development", Journal of Economic Literature, Vol. XXXI, pp. 762-830.

Bojnec, Š. and Konings, J. (1998), "Job Creation, Job Destruction and Labour Demand in Slovenia”, Leuven Institute for Central and East European Studies, Working Paper 74/1998.

Čučković, N. (1997), "Neslužbeno gospodarstvo i proces privatizacije", Institut za javne financije, Financijska praksa, (21), 1-2.

Faulend, M. (1998), "Sociološka pozadina korupcije i antikorupcijska strategija”, Poslovni Savjetnik No. 10/98.

Faulend, M. and Šošić, V. (1999), "Uravnoteženost proračuna, inflacija i rast u tranzicijskim zemljama", mimeo.

Feige, E. (1999), "Underground Economies in Transition: Noncompliance and Institutional Change", mimeo.

Feige, E. (1990), "Defining and Estimating Underground and Informal Activities: The New Institutional Economics Approach", World Development, 18 (7).

Franičević, V. (1997a), "Politička ekonomija neslužbenog gospodarstva - Država i regulacija", Institut za javne financije, Financijska praksa, (21), 1-2.

Franičević, V. (1997b), "Temeljne značajke neslužbenog gospodarstva", Institut za javne financije, Financijska praksa, (21), 1-2.

Gatarić, Lj. (1998), "Sindikati postali direktorske 'postrojbe za posebne namjene”, Poslovni svijet, 5. V. 1998.

Giles, D.E.A. (1998), "Modelling the Hidden Economy and the Tax-gap in New Zealand", Econometrics Working Paper, EWP9810.

Grčar, I. (1999), "Državna riznica na sporednom kolosijeku", Poslovni svijet, 21. IV. 1999.

Hrvatska narodna banka, “Godišnje izvješće 1998”.

Ivanković, Ž (1998), “Guverner tražio 'koordinaciju' još prije pola godine”, Poslovni svijet, 11. XI. 1998.

Johnson, S.; Kaufmann, D. and Shleifer A. (1997), "The Unofficial Economy in Transition", Brooking Papers on Economic Activity, Macroeconomics II.

Kesner-Škreb, M. (1997), "Neslužbeno gospodarstvo i razvoj", Institut za javne financije, Financijska praksa, (21), 1-2.

Kesselman, J.R. (1995), "Policy Implications of Tax Evasion and the Underground Economy", The Centre for Research on Economic and Social Policy, UBC Discussion Paper DP 95-10. 
Mauro, P. (1996), "The Effects of Corruption on Growth, Investment, and Government Expenditure", IMF Working Paper, WP/96/98.

"Neću platit!",, Banka, studeni 1998., br. 11.

Ott, K. (1998), "Tax Administration Reform in Transition: The Case of Croatia”, Institute of Public Finance, Occasional Paper Series, No. 5.

Ott, K. (1997), "Gospodarska politika i neslužbeno gospodarstvo", Institut za javne financije, Financijska praksa, (21), 1-2.

Privatizacija, special issue, October 1998.

Rosen H. S. (1995), "Public Finance", McGraw-Hill, 4th ed.

Tanzi, V. (1994), “Corruption, Governmental Activities, and Markets”, IMF Working Paper, WP/94/99.

Tanzi, V. (1997), "The Changing Role of the State in the Economy: A Historical Perspective", IMF Working Paper, WP/97/114.

Tanzi, V. (1998), "Corruption Around the World: Causes, Consequences, Scope, and Cures", IMF Working Paper, WP/98/63.

Tanzi, V. and Davoodi, H. (1998), "Roads to Nowhere: How Corruption in Public Investment Hurts Growth", IMF, Economic Issues No. 12.

Tanzi, V. and Parthasarathi S. (1993), "A Primer on Tax Evasion", IMF Working Paper, $\mathrm{WP} / 93 / 21$.

Tanzi, V. and Pellechio, A. (1995), "The Reform of Tax Administration", IMF Working Paper, WP/95/22.

Transition Report 1998, European Bank for Reconstruction and Development.

Transparency International: “1998 Corruption Perceptions Index”, Press Release.

Varošanec, S. (1998), "Poduzetnici radije u stečaj nego na sud s državom", Poslovni svijet, 25. XI. 1998.

Varošanec, S. (1999), "Prohujalo s vihorom", Banka, br. 2.

WIIW Handbook of Statistics - Countries in Transition 1998. 